\title{
Anxiety presented by children facing dental treatment
}

\author{
Ansiedade apresentada por crianças frente ao tratamento odontológico \\ Cícera Alane de OLIVERA ${ }^{1}$ \\ (iD) ORCID iD 0000-0001-7972-5781 \\ Tamara GAMA ${ }^{1}$ \\ (i) ORCID ID 0000-0002-9099-4747 \\ Evalena Lima CABRAL ${ }^{1}$ \\ (iD) ORCID iD 0000-0002-6253-5188 \\ Camila Helena Machado da Costa FIGUEIREDO' \\ (iD) ORCID iD 0000-0002-1340-4042 \\ Gymenna Maria Tenório GUÊNES ${ }^{1}$ \\ (D) ORCID iD 0000-0002-5447-0193 \\ Elizandra Silva da PENHA ${ }^{1}$ \\ (iD) ORCID iD 0000-0001-6264-5232
}

\section{ABSTRACT}

\section{Objective}

To determine the profile of children from 6 to 12 years of age, in relation to anxiety towards dental treatment and evaluate the main factors that trigger anxiety in this population.

\section{Methods}

The sample was composed of 200 children with an average age of 8.5 years who attended the Clinic of the School of Dentistry of the Federal University of Campina Grande and the Basic Healthcare Units of the municipality of Patos, Paraiba, Brazil between June 2015 and May 2016. Anxiety was assessed using the Dental Anxiety Scale and the Venham Picture Test. The Chi-Square test and Fisher's exact test were used to explore the level of significance of the associations between the variables

\section{Results}

Anxiety was observed in the majority of children (Dental Anxiety Scale - 89\% and Venham Picture Test - 70.5\%) and the predominant levels were low to moderate. The child's age group was significantly associated with anxiety $(p=0.014)$ by the Venham Picture Test, while gender did not present this correlation. Anxiety was influenced by all the factors studied: making the appointment, waiting room, rotary instrument and periodontal scaling.

\section{Conclusion}

The majority of children presented anxiety and the trigger factors: making the appointment, waiting room, rotary instrument and periodontal scaling contributed considerably to its development.

Indexing terms: Anxiety to dental treatment. Children. Dentist-Patient.

\section{RESUMO}

\section{Objetivo}

Determinar o perfil das crianças de 6 a 12 anos de idade, com relação à ansiedade frente ao tratamento odontológico e avaliar os principais fatores desencadeadores de ansiedade nesta população.

\section{Métodos}

A amostra foi composta por 200 crianças com idade média de 8,5 anos que frequentaram a Clínica-Escola de Odontologia da Universidade Federal de Campina Grande e as Unidades Básicas de Saúde da Família do município de Patos-PB entre junho de 2015 e maio de 2016 . A ansiedade foi avaliada utilizando a Dental Anxiety Scale e o Venham Picture Test. O teste Qui-Quadrado e Exato de Fisher foram usados para explorar o nível de significância das associações entre as variáveis.

\section{Resultados}

A ansiedade foi observada na maioria das crianças (Dental Anxiety Scale - 89\% e Venham Picture Test - 70,5\%) e os níveis predominantes foram baixo e moderado. A faixa etária da criança foi associada significativamente à ansiedade $(p=0,014)$ através do teste Venham Picture Test, ao passo que o gênero não apresentou essa correlação. A ansiedade sofreu influência de todos os fatores estudados: marcação da consulta, sala de espera, caneta odontológica e raspagem periodontal.

\section{Conclusão}

A maioria das crianças apresentou ansiedade e os fatores desencadeadores marcação da consulta, sala de espera, caneta odontológica e raspagem periodontal atuaram consideravelmente para o seu desenvolvimento.

Termos de indexação: Ansiedade ao tratamento odontológico. Crianças. Relações dentista-paciente.

\footnotetext{
${ }^{1}$ Universidade Federal de Campina Grande, Curso de Odontologia, Departamento de Ciências Biológicas. Av. Universitária, s/n, Jatobá, 58708-110, Patos, PB, Brasil. Correspondência para / Correspondence to: CA OLIVEIRA E-mail: <cicera_alane@hotmail.com>.

\section{$\boldsymbol{\nabla} \mathbf{\nabla} \boldsymbol{\nabla}$}

Como citar este artigo / How to cite this article

Olivera CA, Gama TS, Cabral EL, Figueiredo CHMC, Guênes GMT. Elizandra Silva da PENHA1, et al. Anxiety presented by children facing dental treatment. RGO, Rev Gaúch Odontol. 2018;66(3):212-218. http://dx.doi.org/10.1590/1981-863720180003000033302
} 


\section{INTRODUCTION}

Anxiety is an undifferentiated emotional reaction characterized by not identifying the causative object of the state of discomfort $[1,2]$. In the majority of cases, this condition of apprehension is difficult for individuals to control by being conscious of it, and it may become pathological when individuals develop it to a degree that is disproportional to the circumstance to which they were exposed [3]. This emotional state has a multifactorial etiology that is influenced by individual internal factors and by the environment in which the individual lives [4]. Anxiety is manifested in a different way in each individual, generally presenting symptoms such as gradually increasing inner restlessness, feeling of agitation and tension $[1,4]$.

In dentistry, anxiety represents a factor that makes it difficult to perform dental attendance, because the anxious patient tends to avoid treatment, thereby negatively interfering in oral health care $[1,4,5]$.

Pediatric patients commonly present anxiety when faced with dental treatment, and this feeling is generally caused by the use of instruments of which children have had no previous and negative previous experiences. It may also be influenced by factors such as age, gender and personality $[6,7]$.

Dentists' knowledge about the levels of pediatric patients' anxiety before beginning with treatment is important, because this allows professionals to be prepared to deal with the situation and take the necessary steps to reduce its levels $[7,8]$. For correct management of patients in these cases, professionals must have knowledge about the etiology of this emotional state and of the psychology of children [7].

Therefore, the aims of this study were to determine the profile of children from 6 to 12 years of age, relative to anxiety when faced with dental treatment, and evaluate the main trigger factors of anxiety in this population. For this purpose, the following null hypothesis was formulated: that there would be no difference.

Between the age groups and genders studied with regard to the presence of anxiety related to dental attendance.

\section{METHODS}

The research project of this cross-sectional, observational study with an inductive approach was approved by the Research Ethics Committee of the Integrated Faculties of Patos (Certificate of Presentation for Ethical Appreciation - CAAE: 47493015.6.0000.5181).

The convenience sample was composed of children from to 12 years of age, both genders, who had previously experience of dental consultation, and who would be attended at the Clinic-School of Dentistry of the Federal University of Campina Grande (UFCG) and at the Primary Family Health Units (UBSF) of the municipality of Patos-Pb in the period between June 2015 and May 2016. These children presented no sign of developmental cognitive delay, neurological defects and/or psychological disturbances diagnosed or treated, and absence of special needs. The exclusion criteria were: non acceptance of the children and parents of participating in the research, and absence of signature of the Term of Free and Informed Consent (TFIC) by the parents.

The instruments most used for measuring dental anxiety are the following: Dental Anxiety Scale (DASS), Venham Picture Test (VPT), Taylor Manifest Anxiety Scale (TMAS), Frankl Behavior Scale and the Anxiety and Behavioral Scales [9]. The VPT idealized by Venham and Gaulin-Kremer [10] was validated in Brazil by Teixeira et al. (2006)9 and the DASS that was developed by Corah [11] and translated by Pereira, Ramos and Crosato [12] were used in this study for evaluating anxiety. The instruments differ methodologically, since the VPT uses the drawings of children's faces, while the DASS uses a questionnaire.

The VPT is made up of seven cards with the following emotional reactions in the face of dental treatment: neutral (little anxiety), cheerful (absence of anxiety), fear (presence of anxiety), distressed-crying (presence of anxiety), sad (presence of anxiety), anger (presence of anxiety) and panic (presence of anxiety). These drawings of human figures are presented to the children in a size equivalent to half of an A4 page, colored and with drawing of the female gender for girls, and of the male gender for boys[13]. To apply the test, it was necessary for the researcher to ask the children to respond to the following question: "Take a careful look at the face of the figures, and tell me which of these children appears to be feeling the same as you feel right now".

In the DASS scale, the degree of anxiety is measured by the sum of scores of responses about the reactions towards making the appointment, waiting room, rotary instrument and periodontal scaling. This is composed of four multiple-choice questions, and only one response per question must be checked. Each question has five alternative responses, and each alternative receives a score ranging from one to five points, where $a=1, b=2, c=3, d$ 
$=4$, and $=5$. According to the criterion adopted by Corah [11] this sum may vary between 4 and 20 points, with the level of anxiety being classified as null (4 points), low (5 to 10 points), moderate (11 to 15 points) and exacerbated (16 to 20 points).

Before attendance, a researcher applied the scale and test in the waiting room, providing basic explanations about how the instruments should be answered and their objectives. For the children who did not know how to read, the question was asked by the researcher, and the child pointed out the face of the drawing corresponding to his/her response in VPT; and for the DASS scale they spoke their answers. The children's age and gender were recorded and noted on a specific form for later evaluation.

For better analysis of the results, the children researched were divided into two groups according to agerange: 6 to 9 years and 10 to 12 years. This division was made taking into consideration the pertinent characteristics and similarities of the children included in these groups.

The data were statistically analyzed with the help of the program Statistical Package for Social Sciences (SPSS) for Windows, version 13.0, considering a level of significance of $5 \%(p<0.05)$. Association between the variables was verified by the Chi-Square and Exact Fisher tests.

\section{RESULTS}

In total, 200 children participated in the study, of whom 107 (53.5\%) were of the male and 93 (46.5\%) of the female gender, with a mean age of 8.5 years; the majority were attended at the UBSFs (64\%).

To analyze the results obtained by application of the VPT it was necessary to group the codes of this test into three categories: absence of anxiety (code 1 cheerful), little anxiety (code 0 - neutral) and anxiety (code 2 - fear, code 3 - distressed-crying, code 4 - sad code 5 anger, code 6 - panic). From this analysis it was possible to observe the predominance of the emotional reaction of little anxiety (40.5\%) (Table 1). When each code was evaluated individually, the highest percentage mentioned was 0 - neutral $(40.5 \%$ ) (Table 1 ).

When the data of presence/absence of anxiety taken from the VPT were related to the age-range, it was possible to observe that the younger children presented the highest rates of presence of anxiety. The data were submitted to the Chi-Square statistical test, by which statistically significant difference was found $(p=0.014)$ (Table 2). Relative to association with gender, no statistical significance was verified $(p=0.199)$.

The results obtained by the DASS scale demonstrated predominance of the following levels of anxiety: low (41\%) and moderate ( $41 \%$ ) according to the parameter of analysis proposed by Corah (1969)[11] (Table 3).

Table 1. Children's emotional reaction according to the VPT Test Patos, (PB). 2016.

\begin{tabular}{lccc}
\hline \multicolumn{4}{c}{ VPT TEST } \\
\hline CODE & EMOTIONAL & $\mathrm{n}$ & $\%$ \\
0 (Neutral) & REACTION & & \\
1 (Cheerful) & Absence of anxiety & 59 & 29.5 \\
2 (Fear) & Anxiety & 31 & 15.5 \\
3 (Distressed- & Anxiety & 8 & 4 \\
Crying) & Anxiety & 2 & 1 \\
4 (Sad) & Anxiety & 2 & 1 \\
5 (Anger) & Anxiety & 17 & 8.5 \\
6 (Panic) & & 200 & 100 \\
TOTAL & & & \\
\hline
\end{tabular}

Table 2. Association between anxiety and age group by means of the Chi Square test. Patos (PB), 2016.

\begin{tabular}{|c|c|c|c|c|}
\hline \multicolumn{5}{|c|}{ Statistical Analysis - VPT } \\
\hline AGE GROUP & $\begin{array}{l}\text { Without } \\
\text { anxiety }\end{array}$ & $\begin{array}{l}\text { With } \\
\text { anxiety }\end{array}$ & Total & $P$ \\
\hline 1 to 09 years & 44 & 104 & 148 & \\
\hline & & & & $0.014 a$ \\
\hline 10 to 12 years & 15 & 37 & 52 & \\
\hline
\end{tabular}

Table 3. Degree of children's anxiety according to the DAS Scale Patos, 2016.

\begin{tabular}{lcc}
\hline & DASS SCALE & \\
\hline Degree of anxiety & $\mathrm{n}$ & $\%$ \\
Null & 11 & 11 \\
Low & 41 & 41 \\
Moderate & 41 & 41 \\
Exacerbated & 7 & 7 \\
Total & 100 & 100 \\
\hline
\end{tabular}

For didactic purposes, the evaluation of each factor of the DASS scale followed the following criterion: the item relaxed/pleasant experience denoted absence of anxiety, while the sum of the items somewhat uncomfortable/l would not mind; tense/slightly uncomfortable; anxious/ uncomfortable and pain; so anxious that I sweat and feel bad/afraid that what the dentist did would indicate the presence of anxiety. This aggregation of the response was made by the authors of the present study, only with 
a view to categorizing the presence/absence of anxiety. It was possible to observe that all the factors studied: making the appointment, waiting room, rotary instrument and periodontal scaling acted notably on the presence of anxiety. (Table 4).

When anxiety was associated with gender and age-range from the results of the DASS scale, the Exact Fisher test showed no statistically significant differences $(p=0.525)(p=0.722)$.

Table 4. Presence of anxiety in factors evaluated by the DAS SCALE Patos, 2016.

\begin{tabular}{lccccccc}
\hline \multicolumn{7}{c}{ DASS SCALE } \\
\hline Factors & $\begin{array}{c}\text { Letter B } \\
\mathrm{n}(\%)\end{array}$ & $\begin{array}{c}\text { Letter C } \\
\mathrm{n}(\%)\end{array}$ & $\begin{array}{c}\text { Letter D } \\
\mathrm{n}(\%)\end{array}$ & $\begin{array}{c}\text { Letter E } \\
\mathrm{n}(\%)\end{array}$ & $\mathrm{n}$ & $\%$ \\
$\begin{array}{l}\text { Making the } \\
\text { appointment }\end{array}$ & $\begin{array}{c}(28) \\
\begin{array}{l}\text { Waiting } \\
\text { Room }\end{array}\end{array}$ & $13(13)$ & $11(11)$ & $13(13)$ & 65 & 65 \\
$\begin{array}{l}\text { Rotary } \\
\text { instrument }\end{array}$ & 15 & $9(9)$ & $38(38)$ & $15(15)$ & 69 & 69 \\
$\begin{array}{l}\text { Periodontal } \\
\text { Scaling }\end{array}$ & $14(14)$ & $9(9)$ & $26(26)$ & $12(12)$ & 61 & 61 \\
\hline
\end{tabular}

\section{DISCUSSION}

The present study sought to determine anxiety and associated factors in children who awaited dental consultation, by means of using two tests. The authors were able to find elevated presence of anxiety (VPT 70.5\% and DASS 89\%).

Anxiety is based on the emotional state that consists of a response to situations in which the source of threat is not well defined, or is not objectively present, but that becomes persistent and disagreeable to the individual. Whereas, fear is an emotion that provides a state of alert resulting from a physical and psychological threat in the face of a specific situation or object [14].

Before beginning with any treatment, it is feasible to analyze possible trigger factors of anxiety, since this has a multifactorial origin [15]. Among the factors that predispose to anxiety within the scope of dental treatment, it is feasible to mention psychological aspects, the frequency of consultations, the parents' anxiety and fear of the unknown [16]. In the present research, when evaluating the factors that stimulate anxiety: making the appointment, waiting room, rotary instrument and periodontal scaling, by means of the DASS scale, the authors verified that the parameters studied acted considerably on the presence of anxiety. This datum is relevant to enable us to seek strategies with a view to diminishing the anxiety related to these factors, making it possible for the treatment to become a positive experience.

Anxiety is something subjective, thus difficult to measure. The literature points out various instruments that propose to measure it, however, there is no way to determine which of these achieve this exactly. For the present research the VPT and DASS scale were used because they are easy to understand and quick to apply.

To discard any failure to understand the questions that were asked, the researcher adequately explained how the instruments should be answered.

The research covered an age range from 6 to 12 years. This age-range was chosen because it most fitted in with the instruments used in the study. For data analysis, grouping was made with the purpose of facilitating evaluation of the results, considering that the grouped age-ranges were similar from a psychological point of view.

The results found pointed out that the levels of anxiety in all the age-ranges varied from low to moderate when the DASS scale was used, similar to the results found by Assunção et al. [17] in which they used the same instrument for measuring anxiety in patients from 8 to 17 years. The percentage of children who presented anxiety in the present study was high (VPT 70.5\% and DAS 89\%), in agreement with the studies of Olle et al. [18] in which they also used the VPT as the instrument for evaluating 48 children; and Pop-Jordanova et al. [19] who conducted a study with 50 children with the aim of measuring anxiety in the face of dental interventions. However, the literary findings of Popescu et al. [20] who also studied children from 6 to 12 years of age, by means of the DASS scale, reported that only $22.68 \%$ of the children presented anxiety.

Bearing in mind that all the children in the present research had previous experience dental consultation, this fact may have influenced the high presence of anxiety, because such experiences are not always pleasant, particularly when they are related to invasive procedures. A second aspect concerns the situations experienced by the parents/guardians, which may also contribute to the development of anxiety, and may be unfavorable to the treatment [1].

An effective solution to reducing the elevated presence of anxiety would be to adapt the dental office, seeking to make the environment more welcoming to the child patient. The methods used for reducing anxiety may be of the telling-showing- doing type, distraction, positive reinforcement, voice control, among others that generally 
showed satisfactory results [1]. Another way of minimizing anxiety consists of adopting [21] regular visits to the dentist, with the purpose of establishing closer contact with the environment [22]. The use of these techniques favor better clinical practice and help children to face therapeutic procedures that up to then were unknown to them. This would reduce the arousal of anxiety states, making it possible to gradually familiarize children with the dentist, smell of the dental office and instruments, particularly with reference to younger children [23]. Thus the approach to anxious patients could be achieved in various ways, and it is up to the professional to analyze each situation and define the best method to apply [24].

When each code of the VPT test was evaluated individually, Code 6 (panic), which represents an emotion of anxiety, was mentioned by 17 children, attaining the percentage of $8.5 \%$, a result that points out significant relevance. Panic is characterized by an emotional state in which fear or anxiety are experienced in an exaggerated or inappropriate manner, generating strong anxiety. This may result from various factors right from the noise of the high-speed pen through to fear of unknown experiences. In the majority of cases, these factors cause evasion and non acceptance of treatment by the patient, and consequently precarious oral health. In view of this reality, it is fundamental for the dentist to re-evaluate the procedures being performed in the consulting room, and seek to minimize the occurrence of these feeling, by means of using efficient techniques [18].

Both instruments (VPT and DASS) used in the present study were shown to be efficient for identifying anxious children. When conducting this research, we could observe that only VPT showed association of anxiety with the age-range. However, DASS enabled exploration of the knowledge of possible causative factors of this emotional state. Because of the waiting time and intercurrences in the present research, not all the children answered the DASS scale.

In the instruments used, there was agreement with regard to the non significance of association between gender and age, however, there was difference with regard to age-range. The VPT test pointed out significance $(p=0.014)$ when age and anxiety were associated, a result contrary to that of the DASS scale. In the literature, the influence of these variables on anxiety differs among the studies. Pereira et al. [25] conducted a study with 60 patients, using the DASS scale to determine the presence anxiety and found no significant differences in anxiety with reference to gender and age-range. On the other hand, Paryab and Hosseinbor [26].

Who elaborated a study with a similar age-range to that studied; Bezabih et al. [27] who studied a population with a mean age of 10.45 years, and measured anxiety by the DASS scale, pointed out that there was statistical difference only from the aspect of age-range.

This difference found may have occurred due to the better understanding of the VPT test (an easily understood visual test) by the children, which is more adequate for younger children [28]. The fact that the DASS scale is composed of multiple-choice questions with different situations, without illustrations, may have made it difficult for some children to understand. Cognitive, physical and emotional development may be responsible for the reduction in anxiety, and the greater capacity for cooperation, as children get older [29]. This fact may be ratified in this study by the association of age and anxiety found in the results of the VPT test. Therefore, there is a tendency for younger children to be more anxious [30]. When these aspects are added together, the fact that some of the children did not answer the DASS scale may have influenced the difference found.

Having knowledge about the levels of anxiety that affect pediatric patients; the procedures most associated with discomfort, and the management techniques is primordial for an adequate attendance. This contributes to an appropriate approach and establishment of a professional/patient relationship of confidence, thereby optimizing oral health and diminishing the need for curative treatments in children [31].

In view of the foregoing, the measurement of anxiety and knowledge of the trigger factors allow the elaboration of control strategies that are indispensable for the evolution of Pediatric Dentistry. A broader exploration by studies with respect to the methods used for reducing anxiety would be interesting, seeking to elucidate the success and applicability of these methods.

\section{CONCLUSION}

Based on the results of the present research, the authors concluded that the majority of the children presented anxiety, and that the trigger factors: making the appointment; waiting room; rotary instrument and periodontal scaling acted to a considerable extent on the development of anxiety. The hypothesis proposed was not confirmed, considering that there was statistical 
difference with regard to age-range.

\section{Collaborators}

CA OLIVEIRA, with acquisition, analysis and interpretation of data. Drafting the article associated to her completion of course work. TS GAMA, conception about this paper and acquisition of data. EL CABRAL, acquisition of data, co-interpretation of data and contributions to conception and desing this paper. CHMC FIGUEIREDO, with acquisition of data and data tabulation. Also contributed of revising it critically this paper. Resising and

1. Marques KBG, Gradvohl MPB, Maia MCG. Medo e ansiedade prévios à consulta odontológica em crianças do município de Acaraú-CE. Rev Bras Prom Saúde. 2010;23(4):358-367. doi:10.5020/18061230.2010.P358

2. Holanda VN, Bezerra AS, Tavares AR, Lima CIR, Mamede LTS, Araújo LRQ, et al. As bases biológicas do medo: uma revisão sistemática da literatura. Rev Interfaces. 2013;1(3):1-15.

3. Silva, ALP. O tratamento da ansiedade por intermédio da acupuntura: umestudo decaso. Psicol Cienc Prof. 2010;30(1):200211. doi: 10.1590/S1414- 98932010000100015

4. Góes MPSD, Domingues MC, Couto GBL, Barreira AK. Ansiedade, medo e sinais vitais dos pacientes infantis. Odontol Clín-Cient. 2010;9(1):39-44.

5. Carrillo-Diaz M, Crego A, Armfield JM, Romero-Maroto M. Treatment experience, frequency of dental visits, and children's dental fear: a cognitive approach. Eur J Oral Sci. 2012; 120:7581. doi: 10.1111/j.1600-0722.2011.00921.x.

6. Lemos B, Rosa S, Marinho AR, Castro MJ, Lourenço M. Andrade C. A dor do paciente pediátrico no consultório dentário. Acta Pediatr Port. 2011; 42(3):123-128.

7. Kilinç G, Akay A, Eden E, Sevinç N, Ellidokuz H. Evaluation of children's dental anxiety levels at a kindergarten and at a dental clinic. Braz Oral Res. 2016;30(1). doi: 10.1590/1807-3107BOR2016.vol30.0072.

8. Sadana G, Grover R, Mehra M, Gupta S, Kaur J, Sadana S. A novel Chotta Bheem-Chutki scale for dental anxiety determination in children. J Int Soc Prev Community Dent. 2016; 6(3):200. doi: 10.4103/2231-0762.183108

9. Teixeira AM, Torriani DD, Pinheiro RT, Almeida BB, Goettems ML, Wendt F. Validação de instrumentos para mensurar ansiedade e comportamento em clínica odontológica infantil. In: XV Congresso de Iniciação Científica, Universidade Federal de Pelotas, 2006.

10. Venham LL, Gaulin-Kremer EA. Self-report measure of situational anxiety for young children. Pediatr Dent. 1979; 1(2):91-96.

11. Corah NL. Development of a Dental Anxiety Scale. J Dent Res. 1969; 48(4):596. doi: 10.1177/00220345690480041801

12. Pereira LHMC, Ramos DLP, Crosato E. Ansiedade e dor em with final approval of the version to be published. GMT GUÊNES, acquisition of data, co-interpretation of data and contributions to conception and desing this paper. Resising and with final approval of the version to be published. ES PENHA, co-interpretation of data and contributions to conception and desing this paper. Revising it critically for important intellectual content. Resising and with final approval of the version to be published.

\section{REFERENCES}

odontologia: enfoque psicofisiopatológico. Rev Assoc Paul Cir Dent. 1995; 49(4):285-290.

13. Rank RCC, Carvalho AS, Raggio D, Cecanho R, Imaparato JCP. Reações emocionais infantis após o atendimento odontológico: avaliação em serviço público mediante premiação. RGO, Rev Gauch Odontol. 2005;53(3):176-180.

14. Felix LF, Brum SC, Barbosa C, Barbosa O. Aspectos que influenciam nas reações comportamentais de crianças em consultórios odontológicos. Rev Pró-Uni. 2016;7(2):13-16. doi: 10.21727/rpu.v7i2.965

15. Costa AMDD, Terra GO, Souza SMP, Terra FS, Freire, GER. Ansiedade ao tratamento odontológico em escolares do ensino médio no município de Alfenas- MG. Braz J Periodontol. 2014;24(2):1-8.

16. D'Alessandro G, Alkhamis N, Mattarozzi K, Mazzetti M, Piana G. Fear of dental pain in Italian children: child personality traits and parental dental fear. J Public Health Dent. 2016 Jun;76(3):17983. doi: 10.1111/jphd.12127

17. Assunção CM, Losso EM, Andreatini R, de Menezes JV. The relationship between dental anxiety in children, adolescents and their parents at dental environment. J Indian Soc Pedod Prev Dent. 2013; 31(3):175. doi: 10,4103 / 0970- 4.388,117977.

18. Ollé LA, Araujo C, Casagrande L, Bento LW, Santos BZ, Dalpian DM. Anxiety in Children submitted to Dental Appointment. PBOCI. 2016;16(1):167-175. doi: 10.4034/PBOCI.2016.161

19. Pop-Jordanova N, Sarakinova O, Markovska-Simoska S, Loleska S. Anxiety and personality characteristics in children undergoing dental interventions. Pril. 2013; 34(3):93-104.

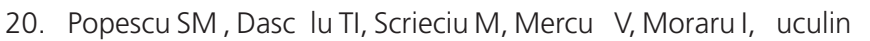
MJ. Dental Anxiety and its Association with Behavioral Factors in Children. Curr Health Sci J. 2014;40(4):261. doi: 10.12865 / CHSJ.40.04.05

21. Rocha RASR, Rolim GS, Moraes ABA. Inclusão de crianças na escolha de estratégias de manejo comportamental em Odontopediatria. Sau \& Transf Soc. 2016;6(1):87-101.

22. Habahbeh, N, Al-Saddi R, Al-Far M. The relationship between dental anxiety and reported dental treatment experience in children aged 11 to 14 years. JRMS. 2012; 19(2):44-50. 
23. Aminabadi AN, Erfanparast L, Sohrabi A, Oskouei GS, Naghili A. The impact of virtual reality distraction on pain and anxiety during dental treatment in 4-6 year- old children: a randomized controlled clinical trial. J Dent Res Dent Clin Dent Prospect. 2012;6(4):117-24. doi: 10.5681/joddd.2012.025

24. Muhammad S, Shyama M, Al-Mutawa SA. Parental attitude toward behavioral management techniques in dental practice with schoolchildren in Kuwait. Med Princ Pract. 2011;20(4):350355. doi: 10.1159/000323758

25. Pereira VZ, de Barreto RC, Pereira GAS, Cavalcanti HRBB. Avaliação dos Níveis de Ansiedade em Pacientes Submetidos ao Tratamento Odontológico. Rev Bras Ci Saúde. 2013;17(1):5564. doi :10.4034/RBCS.2013.17.01.07

26. Paryab M, Hosseinbor $M$. Dental anxiety and behavioral problems: a study of prevalence and related factors among a group of Iranian children aged 6-12. J Indian Soc Pedod Prev Dent. 2013;31(2):82. doi: 10,4103 / 0970-4.388,115699

27. Bezabih S, Fantaye W, Tesfaye M. Dental anxiety: prevalence and associated factors, among children who visited Jimma University Specialized Hospital Dental Clinic. Ethiop Med J. 2013;51(2):115-121.

28. Oliveira MF, De Moraes MVM, Cardoso DD. Avaliação da ansiedade infantil prévia ao tratamento odontológico. Publ
UEPG Ci Biol Saúde. 2012;18(1):31-37. doi: 10.5212/publicatio uepg.v18i1.3736

29. Borges Al, Manso DS, Tomé G, Matos MGD. Ansiedade e coping em crianças e adolescentes: diferenças relacionadas com a idade e género. Anál Psicol. 2008;26(4):551-561.

30. Raja GH, Malik FS, Bashir U, Attaullah. Dental anxiety in children aged between 5 and 10 years a teaching visit dental hospital in Islamabad, Pakistan. J Ayub Med Coll Abbottabad. 2015; 27(3):587-590.

31. Soares FC, Lima RA, Santos CDFBF, de Barros MVG, Colares V. Predictors of dental anxiety in Brazilian 5-7years old children. Compr Psychiatry. 2016;67:46-53. doi: 10.1016/j. comppsych.2016.01.006 